\begin{tabular}{|c|c|}
\hline ב & $\begin{array}{c}\text { International Journal of Current Research } \\
\text { and Academic Review }\end{array}$ \\
\hline$\frac{1}{B L}$ & $\begin{array}{r}\text { ISSN: 2347-3215 (Online) }:, ;=\text { Vol } \\
\text { Journal homepage }\end{array}$ \\
\hline
\end{tabular}

doi: https://doi.org/10.20546/ijcrar.2017.509.008

\title{
Effect of Superheated Steam and Conventional Baking on Physiochemical Properties of High Fiber Bread
}

\author{
Rasha Musa Osman Elawad" and Tajul A. Yang \\ Food Technology Division, School of Industrial Technology, Universiti Sains Malaysia, 11800 Pulau Penang, \\ Malaysia \\ *Corresponding author
}

\section{Abstract}

Effect of superheated steam baking on quality attributes of high fiber bread (HFB) was studied. Superheated steam and conventional ovens were used for baking high fiber bread at 180,200 and $220^{\circ} \mathrm{C}$ for 20,25 and 30 minutes. The moisture content, color $\left(\mathrm{L}^{*}, \mathrm{a}^{*}\right.$ and $\left.\mathrm{b}^{*}\right)$ and texture properties were evaluated using two different heating model with various temperature and time. Moisture content of high fiber bread baked in superheated steam was almost similar to the one baked in conventional oven. Increased baking temperature at constant baking time retained higher moisture content in bread whereas increasing baking time caused reduction in moisture content of high fiber bread crumb in both heating baking models. Baking temperature and time significantly affected the color values of high fiber bread. Superheated steam baking resulted in lighter color as determined by $\mathrm{L}^{*}, \mathrm{a}^{*}$ and $\mathrm{b}^{*}$ values as compared to conventional baking. Bread hardness values increased by increasing baking temperature and time in most bread baked using superheated steam oven. high fiber bread hardness values are similar for superheated steam baked bread at $220^{\circ} \mathrm{C}$ for 25 minutes and conventional baked bread at $200^{\circ} \mathrm{C}$ for 20 minutes $(5.28 \mathrm{~N}$ and $5.27 \mathrm{~N}$ respectively). Springiness of high fiber bread for most heat treatments was almost the same for both superheated steam and conventional ovens.
\end{abstract}

\section{Article Info}

Accepted: 28 August 2017

Available Online: 20 September 2017

\author{
Keywords \\ High fiber bread, \\ Superheated steam oven, \\ Conventional oven, \\ Moisture content, \\ Color and \\ Textural properties.
}

\section{Introduction}

Superheated steam is a type of unsaturated steam generated by adding sensible heat to saturated or wet steam. The additional heat causes increase of steam temperature above saturation or boiling point at a given pressure. Superheated steam is using for drying products, it causes changes such as starch gelatinization, enzyme destruction, protein denaturation, color and texture changes and deodorization (Devahastin et al., 2004), (Tang and Cenkowski, 2000), and (Tang and Cenkowski, 2001).
Superheated steam in food processing is not only used for drying but is also used for heat treatment of food products. Advantages of superheated steam oven over conventional oven include an oxygen free environment, enhanced product quality, improved energy efficiency, higher drying rate, and reduced impact on the environment when condensate is reused (Prachayawarakorn et al., 2004 a, 2006; Prachayawarakorn et al., 2004 b, and Tang et al., 2005). Superheated steam helps in preventing lipid oxidation whilst preserving nutritional components in food products (Sotome and Isobe, 2011). Food products have 
better aroma when dried with superheated steam. Furthermore, some valuable volatile organic compounds could be recovered and separated by the condenser (Karimi, 2010). Superheated steam has been applied to various kinds of food processing such as blanching, pasteurization, extraction, sterilization, and deodorization of the products (Van Deventer and Heijmans, 2001). Recently, it have been used for drying many kinds of food products such as potatoes (Caixeta et al., 2002), grains (Tang and Cenkowski, 2001) and soya bean (Prachayawarakorn et al., 2006).

Bread is an ancient and known staple food that consumed across the globe. White bread is a commonly consumed type of bread. Therefore, to meet the requirement for dietary fiber, the enrichment of bread with a higher dietary fiber content is considered best way to increase the fiber intake. Within this context, bran is an excellent source of dietary fiber. Legume fiber has take less attention compared to cereals fiber in bread making.

Bread baking is the critical step in which the dough is transformed into a light, porous, readily digestible and flavorful product, under impact of heat. Thus, good quality bread production requires a carefully controlled baking process including the rate and amount of heat application and the humidity level in baking chamber and baking time. During baking process, the most apparent interactions of dough are volume expansion, crust formation, inactivation of yeast and enzymatic activities, denaturation of protein and partially starch gelatinization (Pyler, 1988).

The effect of baking time and temperature on bread quality was studied in conventional oven. The end point of baking process depends on quality aspects which are critical in the acceptance of the bread consumer such as color with texture and flavor (Ahrné et al., 2007); (Purlis and Salvadori, 2007). (Maleki et al., 1980) stated that bread with higher moisture content were initially softer and remain softer for three days than that one of low moisture content.

Patel and others observed that faster heating rate produced harder crumb bread, higher melting enthalpy of amylopectin and larger amount of leached amylase (Patel et al., 2005). Borczak and others noticed that the duration of baking affected the degree of starch granules destruction (Borczak et al., 2008). Najafabadi and colleagues observed that decreased baking temperature with increased baking time produced bread with high firmness and low moisture content (Najafabadi et al.,
2014). Shittu and others declared that increased baking temperature and time increased the darkness of bread surface (Shittu et al., 2007). In commercial baking technology, baking temperature and duration used vary. In spite of technological advances and process automation, the bread baking is still a traditional food process and largely depends on skilled technologist and extensive baking experience (Fahloul et al., 1994).

Response surface Methodology (RSM) is statistical technique particularly appropriate for the development of products. RSM was successfully used for baked food (Smith et al., 1988) such as cake (Neville and Setser, 1986); (Vaisey-Genser et al., 1987); (Turabi et al., 2008) and bread (Henselman et al., 1974); (Ylimaki et al., 1988); (Demirekler et al., 2004); (Banu et al., 2011).

Processing techniques based on various heating models were used in baking technology process potentially resulting in improved quality products. Martin et al., (1991) noticed that breads baked in an Electrical Resistance Oven (ERO) became stale more slowly than a conventional oven baked one. Li and Walker (1996) and Yin and Walker (1995), declared that there were improvements in bread and baked products quality by using impingement and hybrid microwave combination ovens as compared with conventional ones ( $\mathrm{Li}$ and Walker, 1996); (Yin and Walker, 1995).

Microwave baking of bread produced product with unacceptable texture (Ovadia and Walker, 1995) giving hard bread crust and crumb (Shukla, 1993). Whereas, Willyard (1998) mentioned slower staling of bakeries when baked with increasing microwave energy in combination with conventional baking.

Most of the studies on the effect of baking temperature and time have been done using the conventional oven for baking and some other heating methods such as infrared, combination heating and microwave oven. Superheated steam has not been introduced for baking process. Such study will assist in the design and development of successful implementation of commercial baking technology.

The objective of the present study was to compare the effect of two factors (temperature and time) on selected physiochemical characteristic of bread baked in superheated steam and conventional ovens using response surface methodology (RSM). The physiochemical characteristics studied including moisture content, color and textural properties of bread. 


\section{Materials and Methods}

Wheat flour, soya bean (Glycine max), salt and dry yeast were obtained from the market in Penang, Malaysia. The chemicals of analytical grade were obtained from School of Industrial Technology, Universiti Sains Malaysia, Malaysia.

\section{Methods}

\section{Bread Preparation and Baking Test}

For obtaining high fiber bran, soya been seeds were cleaned by aspiration, sieving and manual separation of impurities. Then seeds were decorticated, milled and sieved at 355 mesh. Straight dough method was used for preparing the bread dough according to Badi and colleagues (Badi et al., 1978) with some modification, using the following formula:

Flour $=250 \mathrm{gms}$, Dry yeast $=2.5 \mathrm{gms}, \quad$ Salt $=2.5 \mathrm{gms}$, Ascorbic acid $=80 \mathrm{ppm}$ and water $=175 \mathrm{ml}$. soya bean fiber was added at $4 \%$ substitution of the wheat flour.

All ingredients were mixed by a mixer (Spar Food Machinery MFG model 800 - C) for 5 minutes then the dough was placed into incubator (Broofer Bakbar E81) at $30^{\circ} \mathrm{C}$ and medium relative humidity for fermentation. After 20 min the dough was taken out of the incubator, punched, divided into rounded dough balls and placed into the incubator again for another $20 \mathrm{~min}$ under the same condition. The dough was divided into $120 \mathrm{~g}$ pieces after fermentation. Each piece was shaped and placed in baking tin into the incubator for the final proof for 15 min under the same incubation condition for fermentation. The baking was performed using superheated steam oven (Healsio, AV-1500V, SHARP) in superheated steam model and conventional model (normal without steam). Preheat was carried out to reach the specific oven temperature then, the fermented dough samples were baked at 180,200 and $220^{\circ} \mathrm{C}$ for 20,25 and $30 \mathrm{~min}$ for each temperature. Three loaves of breads were baked at a time.

\section{Moisture content}

Moisture content was determined according to the Association of Official Analytical Chemistry Method (Association of Official Analytical Chemistry 2000). The bread samples were grinded using a blender. $5 \mathrm{~g}$ bread sample was put in an oven (Oven Memmert UM 600) at $105^{\circ} \mathrm{C}$ overnight, and then the dried sample was stored in the dessicator for $30 \mathrm{~min}$ equilibrium. All samples were analyzed in triplicate. The moisture content percentage was calculated according to the following equation:

Moisture content $(\%)=\frac{\text { wet weight }- \text { dry weight }}{\text { Dry weight }} \times 100$

\section{Color measurement}

Crust color of the bread samples was measured using a Minolta color reader (Minolta CM- 3500D colorimeter) after calibration against white and black glass standard. Color was expressed in CIELAB color values ( $\mathrm{L}^{*}, \mathrm{a}^{*}$, and $\left.\mathrm{b}^{*}\right)$. The $\mathrm{L}^{*}$ value represents the lightness to darkness, the $\mathrm{a}^{*}$ value represents the greenness to redness spectrum, while the $b^{*}$ value represents the blueness to yellowness. Six readings were carried out from different positions of the bread crust, and then the mean value was calculated.

\section{Texture measurement}

Hardness and springiness of bread were measured using texture analyzer (CNS, Farnell, UK) bread was compressed for $50 \%$ using $75 \mathrm{~mm}$ cylindrical probe. Six readings were carried out of each type of bread.

\section{Statistical analysis}

Response surface methodology (RSM) was used for simultaneous effect of baking temperature and time as well as for plotting graphs and correlations. Three levels for baking temperature and time were $180{ }^{\circ} \mathrm{C}, 200^{\circ} \mathrm{C}$, and $220^{\circ} \mathrm{C}$ and 20 minutes, 25 minutes and 30 minutes respectively.

\section{Results and Discussion}

\section{Moisture content}

Moisture content of high fiber bread baked in superheated steam and conventional oven is shown in Figure 1. Moisture content of bread baked in superheated steam and conventional ovens increased by increasing temperature at fixed baking time and this was due to the degree of starch gelatinization and early formation of bread crust that caused prevention of moisture evaporation of bread during baking. This trend is observed by other researchers who stated that increased temperature of baking at steady baking time retained 
higher moisture content in bread whereas increased baking time caused reduction in moisture content of bread crumb (Shittu et al., 2007); (Faridi and Rubenthaler, 1984); (He and Hoseney, 1990). Similarly, increased baking time in the same baking temperature caused decrease in moisture content of bread in both superheated steam and conventional ovens as can be seen in Fig (1.Aand 1.B) and this is due to higher evaporation rate of water during baking process. This trend was also noticed by other researchers when they used conventional and some other heating methods as an alternative to conventional heating including infrared and hot air assisted microwave heating (Datta and $\mathrm{Ni}, 2002$ ) microwave-hot air combination heating (Lu, Tang, and Liang,1998), impingement hybrid heating ( $\mathrm{Li}$ and Walker, 1996) and halogen lamp-microwave (Keskin et al., 2004).

The obtained result of moisture content is similar with that obtained by Shittu and others, and Wagner and others (Shittu et al., 2007). Faridi and Rubenthaler found that the temperature and time of baking process affected degree of starch gelatinization (Faridi and Rubenthaler, 1984). Generally, gelatinization of starch absorbs moisture. The difference in bread moisture content due to baking time is more obvious than that one of the temperature variance.

As can be seen in Figure 1, most bread baked in superheated steam oven had almost the same moisture content as compared to conventional one such that one baked in $200^{\circ} \mathrm{C}$ for 30 minutes $(36.59 \%$ and $36.57 \%$ respectively). Some of the conventional baked bread had a little bit higher moisture content as compared to superheated steam one. This was expected as unsaturated steam generated by additional sensible heat to saturated or wet steam in superheated steam oven caused loss in moisture. Keskin and others observed that microwave oven caused more loss in moisture of bread as compared to conventional one (Keskin et al., 2004). In addition to slowing down the firming process of bread, moisture content of bread and bakery products is an important marketing tool that affect consumer purchase decision (He and Hoseney, 1990) and (Cauvain and Young, 2009).

\section{Color}

The analysis of high fibre bread color was measured using $\mathrm{L}^{*}, \mathrm{a}^{*}$ and $\mathrm{b}^{*}$ color system. The $\mathrm{L}^{*}, \mathrm{a}^{*}$ and $\mathrm{b}^{*}$ color values stand for lightness, redness and yellowness of the color components respectively. The results of color of high fiber bread using various baking temperature and time are provided in Figure (2, 3 and 4).

Temperature and time in baking process affected bread color. Temperature and time of baking process had negative linear relationship with $\mathrm{L}^{*}, \mathrm{a}^{*}$ and $\mathrm{b}^{*}$ of bread color values. The result showed that increasing baking temperature and time caused obvious reduction in $\mathrm{L}^{*}$ value thus, darker bread color. This result is agree with that obtained by Shittu and others, and Therdthai and others (Shittu et al., 2007); (Therdthai et al., 2002). The difference in high fiber bread color between conventional and superheated steam baked bread is obvious as superheated steam baked breads were lighter and brighter than those baked using conventional oven in terms of color. Whereas Keskin and others observed minimum difference in color between bread baked in conventional and combined ovens (Keskin et al., 2004). The result was in agreement with other authors who observed the lighter color for the drying products when using superheated steam.

There was no significant difference between $\mathrm{L}^{*}$ values of bread that baked in $220^{\circ} \mathrm{C}$ for 25 minutes using superheated steam oven and $220^{\circ} \mathrm{C}$ for 20 minutes using conventional one (64.63 and 64.37 respectively) as well as bread that baked in $200^{\circ} \mathrm{C}$ for 30 minutes and $220^{\circ} \mathrm{C}$ for 20 minutes using conventional oven (64.34 and 64.37 respectively). Superheated steam causes changes such as starch gelatinization, enzyme destruction, protein denaturation, color and texture changes and deodorization (Devahastin et al., 2004); (Tang and Cenkowski, 2000); (Tang and Cenkowski, 2001). Superheated steam in food processing has not only used for drying but also for heat treatment of food products and this is due to the advantages of superheated steam oven over convection oven including enhance product quality and preservation of nutritional components in food products (Sotome and Isobe, 2011). Increase in temperature and time caused increase in $a^{*}$ and $b^{*}$ values of color in both heat treatments.

The factors that governed the color of bread are the moisture evaporation of dough and Maillard reaction during the baking process. Purlis and Salvadori studied the development of browning during baking using natural and forced convection at 180,200 and $220^{\circ} \mathrm{C}$ (Purlis and Salvadori, 2007). They stated that good color of bread crust is yellow to gold in Argentina. Generally consumers perceive pale bread as not well cooked and can easily undergo microbial damage and staling while the dark one is over-cooked and burn bread. 
Fig.1 Moisture content of HFB baked in superheated steam (A) and conventional ovens (B)

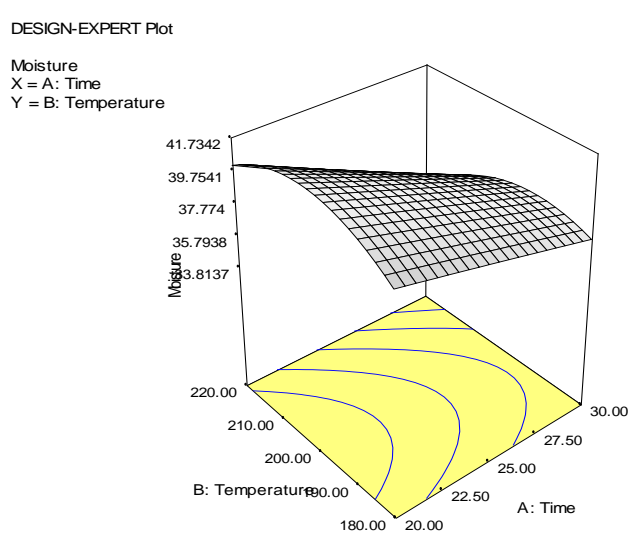

A: superheated steam oven

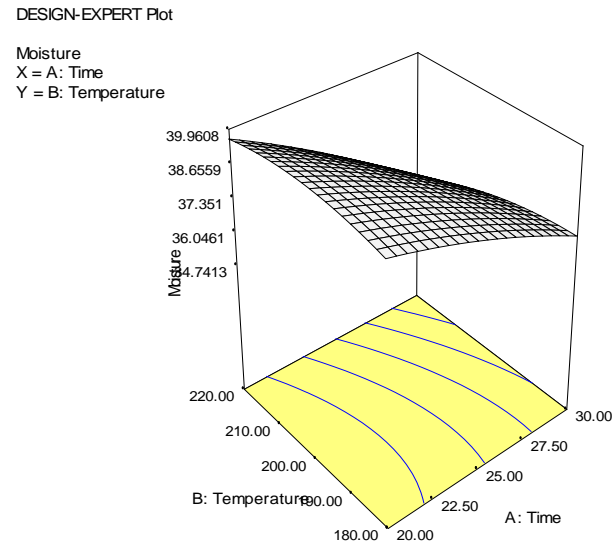

B: conventional oven

Fig.2 L* color values of HFB baked in superheated steam (A) and conventional ovens (B)

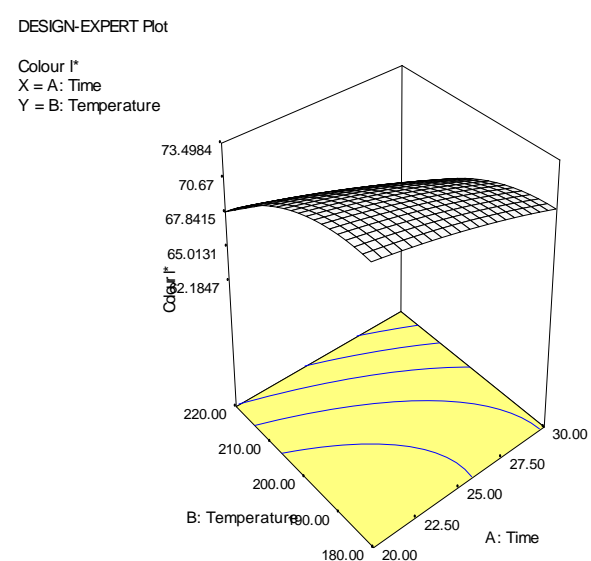

A: superheated steam oven

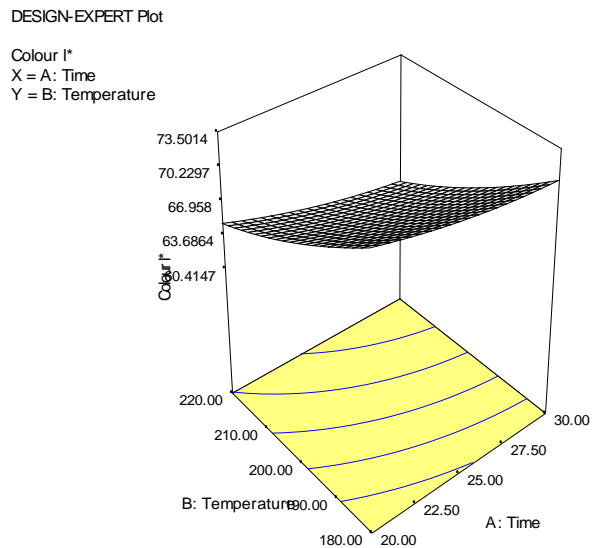

B: conventional oven

Fig.3 a* Color values of HFB baked in superheated steam (A) and conventional ovens (B)



A: Superheated steam oven

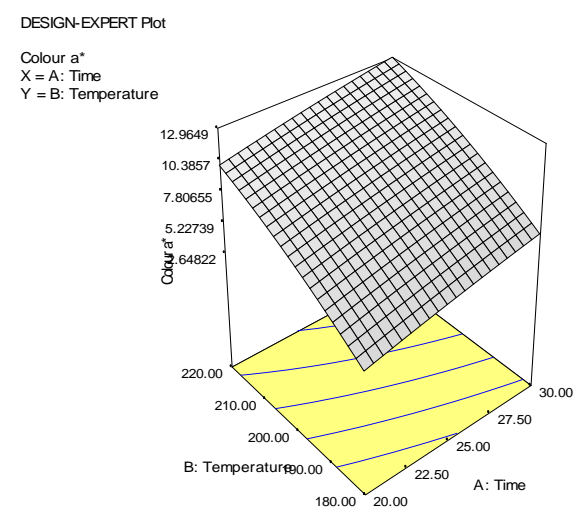

B: conventional oven 
Fig.4 b* Color values of HFB baked in superheated steam (A) and conventional ovens (B)

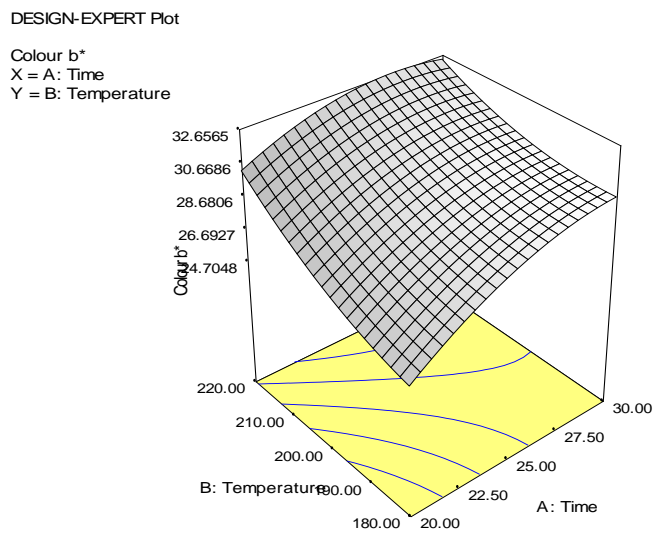

A: Superheated steam oven

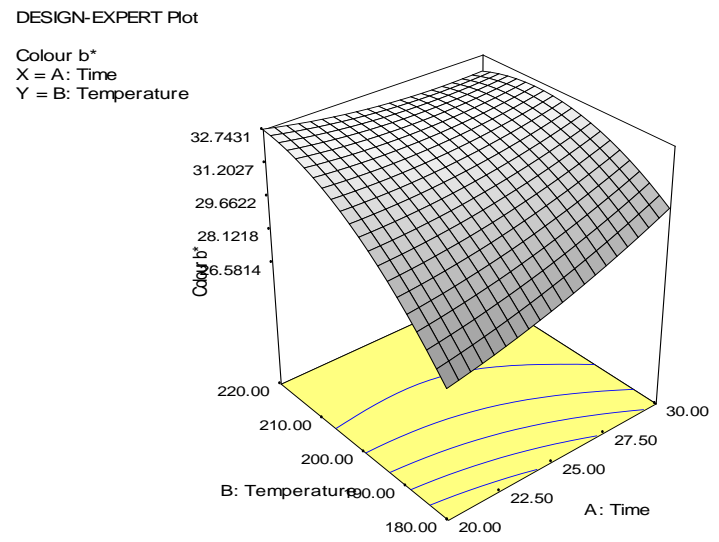

B: conventional oven

Fig.5 Hardness of HFB baked in superheated steam (A) and conventional ovens (B)

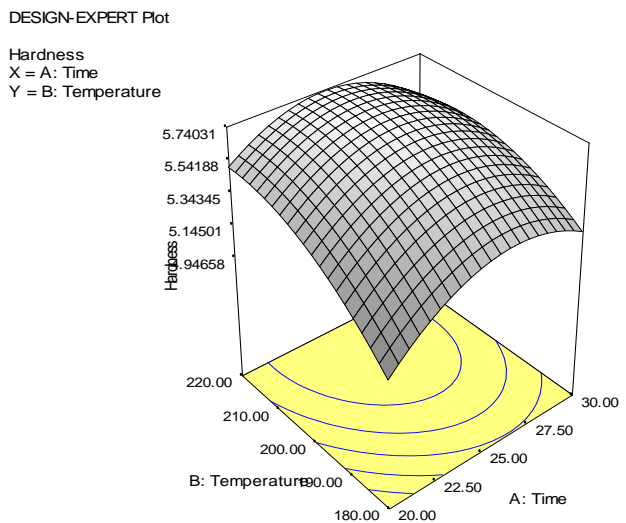

A: superheated steam oven

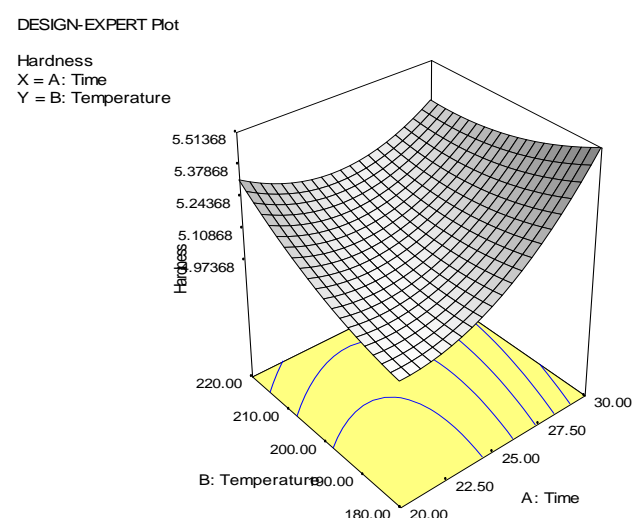

B: Conventional oven

Fig.6 Springiness of HFB baked in superheated steam (A) and conventional ovens (B)

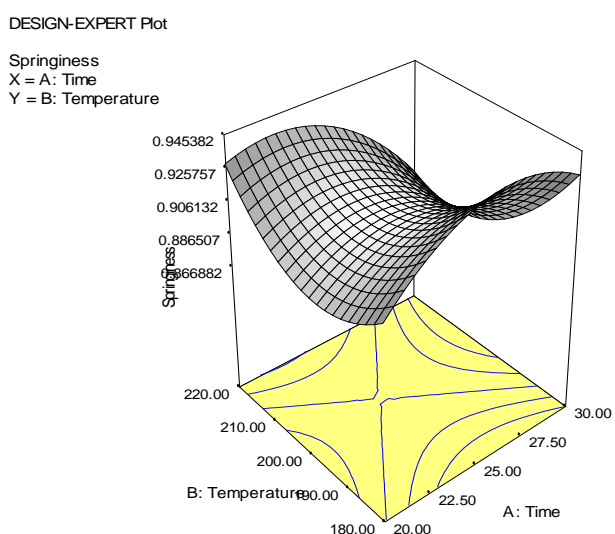

A: superheated steam oven

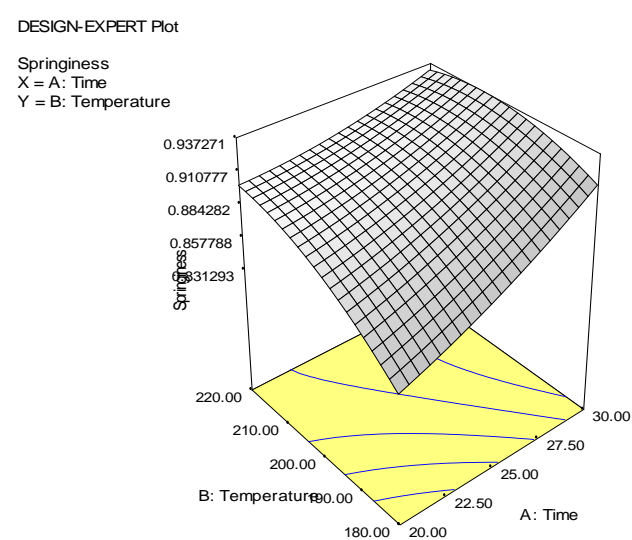

B: conventional oven 


\section{Texture}

The texture as function of baking temperature and time is given in Fig (5 and 6). The differences observed in high fiber bread hardness are affected by the heating rate and time during baking process in both superheated steam and convention ovens. High fiber read hardness values increased by increase in baking temperature and time in most bread baked using superheated steam and conventional ovens (Figure 5. A and B). Bread hardness values are similar for superheated steam baked bread at $180^{\circ} \mathrm{C}$ for 25 minutes and conventional baked bread at $180^{\circ} \mathrm{C}$ for 30 minutes $(5.52 \mathrm{~N}$ and $5.58 \mathrm{~N}$ respectively) as well as superheated steam baked bread at $220^{\circ} \mathrm{C}$ for 25 minutes and conventional baked bread at $220^{\circ} \mathrm{C}$ for 20 minutes (5.27 N) (Fig 5. A and B).

Various thermal conditions affect starch properties including starch gelatinization, starch retro gradation amylase solubility, pasting viscosity and recrystalization of amylopectin. These various properties affect crumb hardness of bread (Patel et al., 2005). Keskin and others found that increase in baking temperature and time causes increase in bread firmness and highest baking temperature produced the hardest bread (Keskin et al., 2004). Zhang and others noticed that an early formation of crust bread limits expansion and produced bread with intensive structure that caused bread hardness (Zhang et al., 2007).

Springiness of high fiber bread from most heat treatment of bread was almost the same for both superheated steam and conventional ovens as provided in figure (6). Patel and colleagues noticed that the combination of convection heating and microwave heating gives a small difference in crispiness when compared with just convection one (Patel et al., 2005). Crumb structure of bread is a critical and an important factor that determining the sensorial quality attributes as can quantified texture and crispiness as well as storage and staling properties of the end product (Mondal and Datta, 2008).

Increase in baking temperature at a steady baking time resulted in higher moisture content in high fiber bread due to early crust formation whereas increase in baking time caused reduction in moisture content in both heat treatments of baking. Baking temperature and time had negative linear relationship with $\mathrm{L}^{*}$ color values of bread. Superheated steam baking resulted in lighter color as determined by $\mathrm{L}^{*}, \mathrm{a}^{*}$ and $\mathrm{b}^{*}$ values as compared to conventional baking. High fiber bread hardness values were similar for superheated steam baked bread at $180^{\circ} \mathrm{C}$ for 25 minutes and conventional baked bread at $180^{\circ} \mathrm{C}$ for 30 minutes $(5.52 \mathrm{~N}$ and $5.58 \mathrm{~N}$ respectively) as well as superheated steam baked bread at $220^{\circ} \mathrm{C}$ for 25 minutes and conventional baked bread at $220^{\circ} \mathrm{C}$ for 20 minutes $(5.27 \mathrm{~N})$.

Bread is one of the oldest staple and important foods having been consumed across the globe. Using superheated steam model heating in baking is a future prospect in the banking industry that may lower cost and reduce negative environmental impact in addition to producing bread with good color, moisture and textural properties.

\section{Acknowledgement}

Deep acknowledgment to USM fellowship scheme of Institute of Postgraduate Studies, Universiti Sains Malaysia for funding this study.

\section{References}

Ahrné, L., Andersson, C.-G., Floberg, P., Rosén, J., and Lingnert, H. 2007. Effect of crust temperature and water content on acrylamide formation during baking of white bread: steam and falling temperature baking. LWT-Food science and Technology. 40 (10):1708-1715.

Banu, I., Vasilean, I., Constantin, O., and Aprodu, I. 2011. Prediction of rye dough behaviour and bread quality using response surface methodology. Irish Journal of Agricultural and Food Research. 239-247.

Borczak, B., Pisulewski, P. M., Sikora, M., and Krawontka, J. 2008. Comparison of glycemic responses to frozen and non-frozen wheat rolls in human volunteers-a short report. Polish Journal of Food and Nutrition Sciences. 58(3).

Caixeta, A. T., Moreira, R., and Castell- Perez, M. E. 2002. Impingement drying of potato chips. Journal of Food Process Engineering. 25(1): 63-90.

Cauvain, S. P., and Young, L. S. 2009. Bakery food manufacture and quality: water control and effects: John Wiley and Sons.

Datta, A., and Ni, H. 2002. Infrared and hot-air-assisted microwave heating of foods for control of surface moisture. Journal of Food Engineering. 51(4): 355-364.

Demirekler, P., Sumnu, G., and Sahin, S. 2004. Optimization of bread baking in a halogen lampmicrowave combination oven by response surface 
methodology. European Food Research and Technology. 219(4): 341-347.

Devahastin, S., Suvarnakuta, P., Soponronnarit, S., and Mujumdar, A. 2004. A comparative study of low-pressure superheated steam and vacuum drying of a heat-sensitive material. Drying

Technology. 22(8): 1845-1867.

Fahloul, D., Trystram, G., Duquenoy, A., and Barbotteau, I. 1994. Modelling heat and mass transfer in band oven biscuit baking. LWT-Food science and Technology. 27(2): 119- 124.

Faridi, H., and Rubenthaler, G. 1984. Effect of baking time and temperature on bread quality, starch gelatinization, and staling of Egyptian balady bread. Cereal Chem. 61(2): 151-154.

He, H., and Hoseney, R. 1990. Changes in bread firmness and moisture during long-term storage. Cereal Chem. 67(6): 603-605.

Henselman, M., Donatoni, S., and Henika, R. 1974. Use of response surface methodology in the development of acceptable high protein bread. Journal of Food Science. 39(5): 943-946.

Karimi, F. (2010). Applications of superheated steam for the drying of food products. Int. Agrophysics. 24(2): 195-204.

Keskin, S. O., Sumnu, G., and Sahin, S. 2004. Bread baking in halogen lamp-microwave combination oven. Food Research International. 37(5): 489-495.

Li, A., and Walker, C. 1996. Cake baking in conventional, impingement and hybrid ovens.

Journal of Food Science. 61(1): 188-191.

Lu, L., Tang, J., and Liang, L. 1998. Moisture distribution in spherical foods in microwave drying. Drying Technology. 16(3-5): 503-524.

Maleki, M., Hoseney, R., and Mattern, P. 1980. Effects of loaf volume, moisture content, and protein quality on the softness and staling rate of bread. Cereal Chem. 57(2): 138-140.

Mondal, A., and Datta, A. 2008. Bread baking-a review. Journal of Food Engineering. 86(4): 465474.

Najafabadi, L. I., Le-Bail, A., Hamdami, N., Monteau, J.-Y., and Keramat, J. (2014). Impact of baking conditions and storage temperature on staling of fully and part-baked Sangak bread. Journal of Cereal Science. 60(1): 151-156.

Neville, N., and Setser, C. 1986. Textural optimization of reduced-calorie layer cakes using.response surface methodology. Cereal foods world (USA).

Ovadia, D., and Walker, C. 1995. Microwave baking of bread. Journal of microwave power and electromagnetic energy. 30(2): 81-89.
Patel, B., Waniska, R., and Seetharaman, K. 2005. Impact of different baking processes on bread firmness and starch properties in breadcrumb. Journal of Cereal Science. 42(2): 173-184.

Prachayawarakorn, S., Prachayawasin, P., and Soponronnarit, S. 2004 b. Effective diffusivity and kinetics of urease inactivation and color change during processing of soybeans with superheatedsteam fluidized bed. Drying Technology. 22(9): 2095-2118.

Prachayawarakorn, S., Prachayawasin, P., and Soponronnarit, S. 2006. Heating process of soybean using hot-air and superheated-steam fluidized-bed dryers. LWT-Food science and Technology. 39(7): 770-778.

Prachayawarakorn, S., Soponronnarit, S., Wetchacama, S., and Chinnabun, K. 2004 a. Methodology for enhancing drying rate and improving maize quality in a fluidised-bed dryer. Journal of stored products research. 40(4): 379-393.

Purlis, E., and Salvadori, V. O. 2007. Bread browning kinetics during baking. Journal of Food Engineering: 80(4): 1107-1115.

Pyler, E. (1988). Keeping properties of bread. Baking science and technology, 2, 815-849.

Shittu, T., Raji, A., and Sanni, L. 2007. Bread from composite cassava-wheat flour: I. Effect of baking time and temperature on some physical properties of bread loaf. Food Research International. 40(2): 280-290.

Shukla, T. 1993. Bread and bread-like dough formulations for the microwave. Cereal Foods World, 38(2): 95.

Smith, J., Khanizadeh, S., Van de Voort, F., Hardin, R., Ooraikul, B., and Jackson, E. 1988. Use of response surface methodology in shelf life extension studies of a bakery product. Food Microbiology. 5(3): 163-176.

Sotome, I., and Isobe, S. 2011. Food processing and cooking with new heating system combining superheated steam and hot water spray. Japan Agricultural Research Quarterly: JARQ. $\quad 45(1)$ : 69-76.

Tang, Z., and Cenkowski, S. 2000. Dehydration dynamics of potatoes in superheated steam and hot air. Canadian Agricultural Engineering. 42(1): 43-49.

Tang, Z., and Cenkowski, S. 2001. Equilibrium moisture content of spent grains in superheated steam under atmospheric pressure. Transactions of the ASAE. 44(5): 1261-1264. 
Therdthai, N., Zhou, W., and Adamczak, T. 2002. Optimisation of the temperature profile in bread baking. Journal of Food Engineering. 55(1): 41-48.

Turabi, E., Sumnu, G., and Sahin, S. 2008. Optimization of baking of rice cakes in infrared-microwave combination oven by response surface methodology. Food and Bioprocess Technology. 1(1): 6473.

Vaisey-Genser, M., Ylimaki, G., and Johnston, B. 1987. The selection of levels of canola oil, water, and an emulsifier system in cake formulations by response surface methodology. Cereal Chem. 64(1): 50-54.

Van Deventer, H. C., and Heijmans, R. M. 2001. Drying with superheated steam. Drying Technology. 19(8): 2033-2045.

Wagner, M. J., Lucas, T., Le Ray, D., and Trystram, G. 2007. Water transport in bread during baking. Journal of Food Engineering. 78(4): 1167-1173.

\section{How to cite this article:}

Rasha Musa Osman Elawad and Tajul A. Yang. 2017. Effect of Superheated Steam and Conventional Baking On Physiochemical Properties of High Fiber Bread. Int.J.Curr.Res.Aca.Rev. 5(9), 51-59.

doi: https://doi.org/10.20546/ijcrar.2017.509.008
Walker, S. J., Jahns, J., Li, L., Mansfield, W., Mulgrew, P., Tennant, D.,.... and Ailawadi, N. 1993. Design and fabrication of high-efficiency beam splitters and beam deflectors for integrated planar microoptic systems. Applied optics. 32(14): 2494-2501.

Yin, Y., and Walker, C. 1995. A quality comparison of breads baked by conventional versus nonconventional ovens: a review. Journal of the Science of Food and Agriculture. 67(3): 283291.

Ylimaki, G., Hawrysh, Z., Hardin, R., and Thomson, A. 1988. Application of response surface methodology to the development of rice flour yeast breads: Objective measurements. Journal of Food Science. 53(6): 1800-1805.

Zhang, L., Lucas, T., Doursat, C., Flick, D., and Wagner, M. 2007. Effects of crust constraints on bread expansion and $\mathrm{CO} 2$ release. Journal of Food Engineering. 80(4): 1302-1311. 